\title{
The Assessment of the Influence of Cadastral Parcel Boundary Points Location Errors on the Accuracy of Analytical Determination of Their Surface Area**
}

\section{Introduction}

The leading problem of this work is a cadastral parcel which, in accordance with the "superficies solo cedit" principle, constitutes a main object in the register of land and buildings [4]. From the owners' point of view, the boundaries and the surface area (which has a direct influence on, inter alia, the market value of land properties) resulting from them are the most important spatial attributes of a parcel.

It is therefore beyond all doubt that a correct determination of surface areas, maintaining the highest possible accuracy, is an important problem. The truthfulness of this statement is additionally proven by the tasks which are set for contemporary register of land and buildings. Therefore, it is worth considering the influence and range of impact of basic factors deciding on the final value of average error in analytical determination of parcels' surface area.

For conducting the research connected with the presented subject it was necessary to obtain appropriate data from the centres of geodetic and cartographic documentation. Finally, the materials coming from cadastral units located in Częstochowa, Cracow, Opole and Tarnowskie Góry poviats were collected. A broad range of conducted analyses allowed for both describing the current status of data on parcels' boundaries disclosed in register of land and buildings and formulating the conclusions regarding the considered problem.

* AGH University of Science and Technology, Faculty of Mining Surveying and Environmental Engineering, Department of Geomatics, Krakow, Poland

** This article is the result of examinations financed from means for statutory activities no. 11.11.150.006 in the Department of Geomatics, AGH University of Science and Technology, Krakow, Poland 


\section{Cadastral Parcel as a Main Object in Register of Land And Buildings - Real Estate Cadastre}

"A cadastral parcel is a continuous area of land, located within the boundaries of one cadastral unit, homogenous in legal respect, separated from the surroundings by boundary lines" [7]. There is no question that spatial information on such important object should be recorded using appropriate tools, maintaining the highest possible accuracy and reliability. The considerations conducted in this chapter will allow for answering the question if this postulate can be regarded as fulfilled.

According to binding legislation, the register of land and buildings (pol. Ewidencja Gruntów i Budynków), hereinafter referred to as EGiB, is defined as an "information system ensuring collection, updating and making available, in a manner uniform for the entire country, information on lands, building and premises, their owners and other entities which govern or manage such lands, buildings and premises" [9].

Data contained in EGiB are the basis for:

- town and country planning and economic planning,

- calculation of taxes and benefits,

- designation of real estate in land and mortgage registers,

- real estate management,

- public statistics,

- register of farmsteads.

Therefore there is no doubt that both the accuracy and reliability of these data should be sufficiently high so that it would allow a proper completion of tasks which are set for EGiB. In connection with a gradual pursuing at fulfilment of this postulate, the changes are introduced in regulations which govern the principles of data collecting, updating and revealing in the real estate cadastre.

In 2014 the amendments to the Act of 17 May, 1989, Geodetic and Cartographic Law [9] and to the Regulation of the Minister of Regional Development and Construction of 29 March, 2001, on the register of land and buildings [7], hereinafter referred to as the Regulation 2001, entered into force. New regulations have been already widely commented. First and foremost, the provisions regarding the updating and modernizing of EGiB database were changed, which aroused a lot of controversies, related mainly to the problem of determining the route of parcels' boundaries. Until entering the above-mentioned amendments into force, the determination of boundaries was possible only by delimitation of real estate or in the course of completing the tasks related to the modernization of EGiB. At present, a geodesist has such possibility also during an on-going updating of cadastral database. Considering the problem with a very large simplification, a conclusion can be drawn that in accordance with $\S 39$ of the Regulation 2001, a parcel boundary 
will be always determined, irrespective of occurring circumstances, which cannot be assessed in an unambiguously positive manner. As opposed to the delimitation proceeding, which ensures (despite the complexity of procedure) a full solution of the issue with boundaries, as a result of determining the boundaries by EGiB updating, in accordance with $\S 39$ of the Regulation 2001, it is possible to leave a disputable parcel boundary. It is also worth noticing that the definition of reliability of data included in the National Surveying and Cartographic Resource (pol. Państwowy Zasób Geodezyjny i Kartograficzny), hereinafter referred to as PZGiK, has not still been introduced. The introduction of such definition could significantly clarify the wording of binding regulations.

However, there is no doubt that mentioned amendments had a very significant influence on the most important object of EGiB, i.e. the cadastral parcel. This statement regards particularly the boundaries, which constitute the main spatial attribute of a parcel. Attention should be paid to the fact that in amended Regulation 2001 the definition of parcel boundary appeared for the first time: "a part of cadastral parcel circumference, in the form of a broken line or section, common for two adjacent cadastral parcels or overlapping the state border in case of cadastral parcels adjacent to that border" [7]. It results from the quoted provision that the number of boundary sections of a given parcel depends on the number of adjacent parcels. Unfortunately, a term which could be identified with a legal boundary has not been introduced [3].

The interrelations between EGiB objects and the attributes of individual classes, along with allowed values assigned to them, have been presented graphically on UML (Unified Modelling Language) diagrams. It is an effect of legislator's aiming at fulfilling the postulates of interoperability and harmonization of spatial data on the entire territory of the country. As a result of occurred changes, new principles for, inter alia, collecting information on the points of parcel boundary bends, have been introduced. At present, the accuracy with which their location was determined in relation to the class I geodetic control network, is revealed using the "point location error" (the Polish acronym: BPP) attribute, which can, in accordance with the annex no. 1 a to the Regulation 2001, assume the following values:

$$
\begin{aligned}
& 1 \text { - from } 0.00 \mathrm{~m} \text { to } 0.10 \mathrm{~m}, \\
& 2 \text { - from } 0.11 \mathrm{~m} \text { to } 0.30 \mathrm{~m}, \\
& 3 \text { - from } 0.31 \mathrm{~m} \text { to } 0.60 \mathrm{~m}, \\
& 4 \text { - from } 0.61 \mathrm{~m} \text { to } 1.50 \mathrm{~m}, \\
& 5 \text { - from } 1.51 \mathrm{~m} \text { to } 3.00 \mathrm{~m} \\
& 6 \text { - over } 3.00 \mathrm{~m} \text {. }
\end{aligned}
$$

It is very important that prior to the amendment of the Regulation 2001 there was no provision regarding the determination of boundary points location errors in relation to the class I geodetic control network. Only information on error of boundary point location in relation to control network (without its further distinguishing) 
was given. Therefore, these regulations were much less restrictive. In practice it means that the values of BPP attribute of boundary points, which were assigned to them before the amendment entered into force, should be additionally verified and updated.

It is worth noticing here that the value of BPP attribute assigned to the boundary points which were measured prior to entering of the Regulation of the Minister of Internal Affairs and Administration of 9 November, 2011, on the technical standards for the performance of horizontal and height measurements... [8], should be equal to 2. Performing simple calculations, in which the location errors for the points of minor control network and class III detailed control network are assumed as $0.20 \mathrm{~m}$ and $0.10 \mathrm{~m}$ respectively, and taking into consideration the accuracy with which the location of field details belonging to group I $(0.10 \mathrm{~m})$ is determined, we will obtain the value of boundary point location error in relation to the class I geodetic control network equalling to $\sim 0.24 \mathrm{~m}$. In case of boundary points and marks, the location of which is currently determined very often by GNSS satellite measurement, based on the system of ASG-EUPOS reference stations, the BPP attribute assumes usually the value of 1 .

In accordance with $\S 61$, section 1 of the Regulation 2001, the numerical description of boundaries should include only these boundary points which are characterized of location errors not exceeding $0.30 \mathrm{~m}$ in relation to the class I geodetic control network. Unfortunately, as it appears, these requirements are not and in many cases will not be quickly fulfilled. Moreover, the centres of geodetic and cartographic documentation often apply internal rules for revealing information in EGiB database, which results from various interpretations of binding rules of law. In connection to that, the postulate of full harmonization and interoperability of data on the entire territory of the country cannot be currently considered as fulfilled.

The charts below (Figs 1,2) present the share of individual values of BPP for the boundary points of cadastral parcels in selected cadastral units on the territory of Cracow and Tarnowskie Góry poviats.
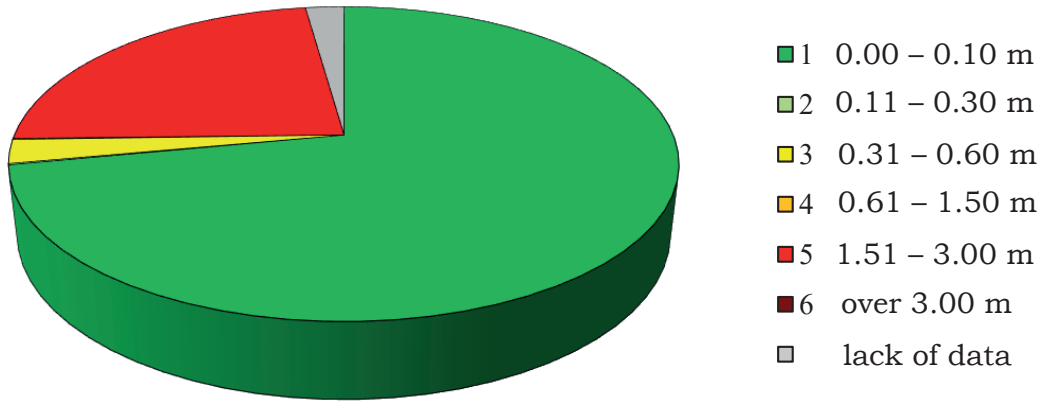

Fig. 1. Share of individual values of BPP attribute for boundary points located in Michałowice cadastral unit, Cracow poviat (status for quarter I, 2015) 

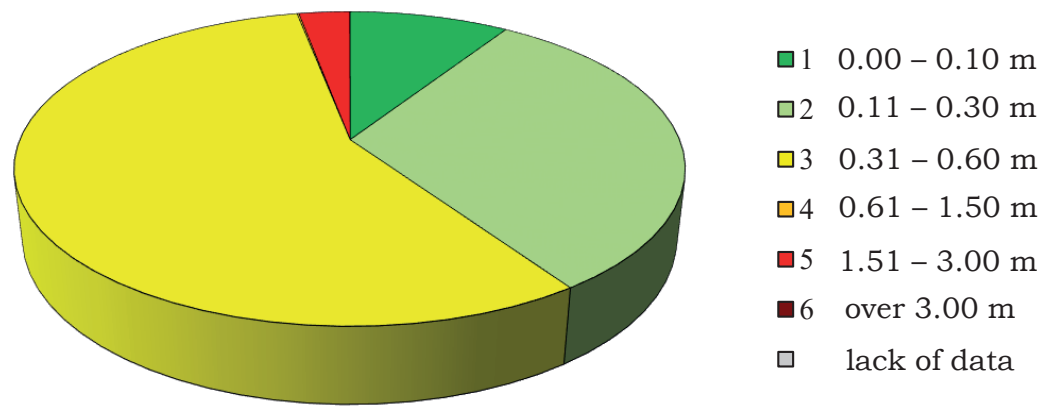

Fig. 2. Share of individual values of BPP attribute for boundary points located in Potępa cadastral unit, Tarnowskie Góry poviat (status for quarter I, 2015)

The presented charts confirm that data on parcel boundaries revealed in PZGiK are characterized by different accuracy. There is still a large percentage of boundary points which do not meet the requirements stipulated in $\S 61$ section 1 of the Regulation 2001. It proves that there is still the necessity to conduct the processes of EGiB updating and modernization. The main purpose of these processes should be aimed at the unification and increasing the accuracy and reliability of data regarding the parcel boundaries. In other words, the numerical description of boundaries should be led to the status stipulated in binding rules of law.

It is worth emphasizing the fact that data regarding the parcel boundaries can still be acquired using each of methods known and applied so far: direct, photogrammetric and cartometric. Information which of them was applied can be obtained indirectly from the values of boundary point attribute "Source of point location data" (the Polish acronym: ZRD). The following assumptions should be made:

$$
\begin{aligned}
& \mathrm{ZRD}=1,2,5,6 \\
& \mathrm{ZRD}=3,4 \\
& \mathrm{ZRD}=7,8,(9)
\end{aligned}
$$

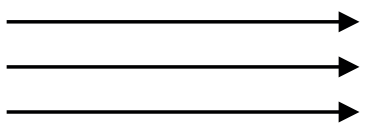

direct method photogrammetric method cartometric method

Then it can be determined, in a simple manner, which method was used the most frequently on the selected area. The percentage share of using the individual methods in the cadastral units listed below is presented in the Table 1: Michałowice (Cracow poviat), Potępa (Tarnowskie Góry poviat), Dobrzeń Wielki (Opole poviat).

Table 1. Share of methods for the acquisition of data regarding the parcel boundaries in cadastral units [\%] (status for quarter I, 2015)

\begin{tabular}{||l|c|c|c||}
\hline \multirow{2}{*}{ Method } & \multicolumn{3}{|c||}{ Cadastral unit } \\
\cline { 2 - 4 } & Michałowice & Potępa & Dobrzeń Wielki \\
\hline \hline Direct & 76.6 & 41.0 & 43.6 \\
\hline Photogrammetric & 0.0 & 0.0 & 35.9 \\
\hline Cartometric & 23.4 & 59.0 & 20.5 \\
\hline
\end{tabular}


The conducted analysis confirms that there is no uniformity also in these aspects. Unfortunately, a large part of data on parcels boundaries, which are revealed in EGiB, was acquired with the cartometric method. It has been already proven many a time that this method should not be applied due to its low accuracy and low reliability of final result [2]. Reliable results will not be acquired with photogrammetric method, neither, if a reliable determination of parcel boundaries is not conducted simultaneously.

As it appears, the issues of accuracy and reliability of concerned data revealed in $\mathrm{EGiB}$, are very important and simultaneously complex problems. On the basis of conducted examinations, it has been ascertained that unfortunately the postulate mentioned at the beginning of this chapter cannot be, at present, considered as fulfilled.

\section{Surface Area as a Derivative of Parcel Boundaries}

The surface area is one of the most important spatial attributes of cadastral parcel. To put it simply, it is a number which determines the size of area occupied by a parcel, demarcated by its boundaries [4]. The importance of the surface area is confirmed by the fact that the surface area is a part of real estate designation in land and mortgage registers.

In accordance with binding legal regulations, the surface areas of parcels must be determined using the analytical method, on the basis of coordinates of their boundary bend points. The surface areas in EGiB are revealed with the precision up to 0.0001 ha, which, as it appears, is not completely justified in each case. It should be also emphasized that since the last amendment of the Regulation 2001, the surface areas should be corrected by a value of surface mapping correction (previously this question was described only in technical instruction G-5 [5]). For the needs of conducted analyses, it was established that taking this correction into accordance is not necessary, because it will not affect the results of examinations and conclusions formulated on their basis. Moreover, the value of mapping correction is often lower than the average errors of parcel surface areas. Its influence is clear only in case of very large objects.

As it was mentioned, the analytical determination of parcels' surface areas is conducted based on the coordinates of the parcel boundary bend points. For that purpose, the formulas, which in their general form are called the Gauss's formulas, are used:

$$
2 P=\sum_{i=1}^{n} X_{i} \cdot\left(Y_{i+1}-Y_{i-1}\right)
$$

or:

$$
-2 P=\sum_{i=1}^{n} Y_{i} \cdot\left(X_{i+1}-X_{i-1}\right)
$$


where:

$$
\begin{gathered}
p \text { - parcel surface area, } \\
n \text { - number of parcel boundary bend points, } \\
X_{i^{\prime}} Y_{i} \text { - coordinates of } i^{\text {th }} \text { point of parcel boundary bend. }
\end{gathered}
$$

The coordinates of boundary points $\left(X_{i}, Y_{i}\right)$ are characterized by a certain accuracy of their determination. It means that they should not be treated as error-free values [1]. Using the Gauss's formula (1) and based on error propagation law, the formula for average error of analytical determination of parcel surface area $\left(m_{S A}\right)$ has been derived. First, the partial derivatives of the function in relation to subsequent variables were calculated and then the following assumptions have been made:

$$
\begin{gathered}
m_{p_{i}}^{2}=m_{X_{i}}^{2}+m_{Y_{i}}^{2} \\
m_{X_{i}}=m_{Y_{i}} \\
m_{X_{i}}^{2}=\frac{m_{p_{i}}^{2}}{2} \text { or } m_{Y_{i}}^{2}=\frac{m_{p_{i}}^{2}}{2}
\end{gathered}
$$

where:

$m_{p_{i}}-$ error of $i^{\text {th }}$ boundary point location,

$m_{X_{i}}$ - average error of determining the $X$ coordinate of $i^{\text {th }}$ boundary point,

$m_{Y_{i}}$ - average error of determining the $Y$ coordinate of $i^{\text {th }}$ boundary point.

Performed operations allowed deriving the formula which will constitute the basis for further analyses:

$$
m_{S A}^{2}=\frac{1}{8} \cdot \sum_{i=1}^{n} m_{p_{i}}^{2} \cdot\left[\left(Y_{i+1}-Y_{i-1}\right)^{2}+\left(X_{i-1}-X_{i+1}\right)^{2}\right]
$$

Assuming additionally that the location errors of all bend points of parcel boundaries are equal, the formula (6) can be further simplified. However, in practice the average value of boundary point location error $\left(m_{p}\right)$ is calculated in most cases:

$$
m_{p}=\frac{1}{n} \sum_{i=1}^{n} m_{p_{i}}
$$

As it appears, such proceeding can lead to a significant fudging of final results. It concerns the parcels with boundary points which are characterized of different values of BPP attribute. It should be noted that in considered case the calculation of arithmetic average means actually making the assumption that the boundary 
bend points of examined objects are distributed evenly. In most cases, however, this postulate is not fulfilled, which leads, depending on considered case, to bigger or smaller discrepancies between the formula (6) and the formula mentioned in $\S 68$ section 2 of the Regulation of the Minister of Internal Affairs and Administration of November 9, 2011, on the technical standards for the performance of horizontal and height measurements... [8]:

$$
d P_{\max }=m_{p} \cdot \sqrt{\frac{1}{8} \cdot \sum_{i=1}^{n} d_{i-1, i+1}^{2}}
$$

Above formula for the allowed value of the difference between the calculated surface area and the parcel surface area revealed in EGiB $\left(d P_{\max }\right)$ has already aroused many controversies, because an error has been made in its description. The component $d_{i-1, i+1}^{2}$ has been described as the shortest diagonal located opposite to the point with the $i^{\text {th }}$ number, while in fact it is the squared shortest diagonal. Thus, the explanation above would be correct, if the designation $d_{i-1, i+1}$ was included in the description of the formula.

It should be emphasized once more that further examinations were conducted on the basis of the formula (6), which ensures a higher reliability of calculations and, simultaneously, is simple in application. The upper limits of intervals corresponding to the individual values of BPP attribute have been assumed as the errors of boundary points location.

\section{Factors Affecting the Accuracy of Analytical Determining the Parcel Surface Area}

Considering the derived formulas it can be concluded that the accuracy of analytical determining the parcel surface areas is affected by:

- errors of boundary points location,

- geometry of parcel,

- number of parcel boundary bend points.

In order to demonstrate the range and significance of influence for each of the considered factors, the pairs of parcels with very similar surface area, differing only in the range of analyzed attribute, should be created. In practice, finding such pairs is not an easy task. In order to make the results of examination more credible, the appropriate objects, which meet the set criteria entirely, have been also generated, in addition to data acquired from PZGiK. However, it should be noted that the final value of surface area average error is affected cumulative by all analyzed factors, irrespectively of circumstances. 
The examples of the pairs of parcels from various cadastral units, which were selected in such a manner so that they are characterized of the most similar surface area, geometry, and identical number of boundary points, are presented in the Table 2 .

Table 2. Influence of boundary points location errors on the accuracy of analytical determining the parcel surface area

\begin{tabular}{|c|c|c|c|c|c|c|c|}
\hline No. & Parcel no. & $\begin{array}{c}\text { Average } \\
\text { BPP } \\
{[\mathrm{m}]}\end{array}$ & $\begin{array}{c}\text { Surface area } \\
\qquad\left[\mathrm{m}^{2}\right]\end{array}$ & $\begin{array}{c}\text { Average } \\
\text { error } \\
{\left[\mathrm{m}^{2}\right]}\end{array}$ & $\begin{array}{c}\text { Difference } \\
{\left[\mathrm{m}^{2}\right]}\end{array}$ & $\begin{array}{c}\text { Relative } \\
\text { error } \\
{[\%]}\end{array}$ & $\begin{array}{c}\text { Difference } \\
{[\%]}\end{array}$ \\
\hline \multicolumn{8}{|c|}{ Cadastral unit: Michałowice } \\
\hline 1 & 56 & 3.00 & 1442 & 122.3 & \multirow{2}{*}{118.3} & 8.5 & \multirow{2}{*}{8.2} \\
\hline $1^{\prime}$ & $90 / 8$ & 0.10 & 1401 & 4.0 & & 0.3 & \\
\hline 2 & $150 / 2$ & 3.00 & 2817 & 170.3 & \multirow{2}{*}{164.3} & 6.0 & \multirow{2}{*}{5.8} \\
\hline $2^{\prime}$ & $95 / 2$ & 0.10 & 2861 & 6.0 & & 0.2 & \\
\hline \multicolumn{8}{|c|}{ Cadastral unit: Zielonki } \\
\hline 3 & 1530 & 0.87 & 3932 & 179.8 & \multirow{2}{*}{166.6} & 4.6 & \multirow{2}{*}{4.3} \\
\hline $3^{\prime}$ & $1460 / 5$ & 0.10 & 3958 & 13.2 & & 0.3 & \\
\hline 4 & $1532 / 1$ & 1.80 & 465 & 113.1 & \multirow{2}{*}{82.8} & 24.3 & \multirow{2}{*}{18.2} \\
\hline $4^{\prime}$ & $2 / 2$ & 0.60 & 492 & 30.3 & & 6.1 & \\
\hline \multicolumn{8}{|c|}{ Cadastral unit: Dobrzeń Wielki } \\
\hline 5 & $739 / 206$ & 3.00 & 2204 & 187.4 & \multirow{2}{*}{72.7} & 8.5 & \multirow{2}{*}{3.3} \\
\hline $5^{\prime}$ & $642 / 1$ & 1.84 & 2217 & 114.7 & & 5.2 & \\
\hline 6 & $1293 / 317$ & 3.00 & 2656 & 313.2 & \multirow{2}{*}{151.8} & 11.8 & \multirow{2}{*}{5.9} \\
\hline $6^{\prime}$ & $254 / 67$ & 1.18 & 2758 & 161.4 & & 5.9 & \\
\hline
\end{tabular}

It is clearly seen that the accuracy of surface area determination decreases significantly with the increase of the value of boundary points' location errors. It is seen in particular in cases 1-1' and 2-2'. Therefore, it can be stated that the errors of boundary points' location influence significantly the accuracy of analytical determining the parcel surface area.

Similar considerations have been also conducted on generated objects, in order to eliminate completely the influence of geometry. The results are presented for the case of elongated rectangle which can be considered as the most frequently encountered shape of parcel. 
Table 3. Errors of surface area determination for hypothetical case (elongated rectangle)

\begin{tabular}{||c|c|c|c|c|}
\hline \multirow{2}{*}{$\begin{array}{c}\text { Average BPP } \\
{[\mathrm{m}]}\end{array}$} & \multicolumn{2}{|c|}{ Surface area: $100 \mathrm{~m}^{2}$} & \multicolumn{2}{c|}{ Surface area: $10000 \mathrm{~m}^{2}$} \\
\cline { 2 - 5 } & $\begin{array}{c}\text { average error } \\
{\left[\mathrm{m}^{2}\right]}\end{array}$ & $\begin{array}{c}\text { relative error } \\
{[\%]}\end{array}$ & $\begin{array}{c}\text { average error } \\
{\left[\mathrm{m}^{2}\right]}\end{array}$ & $\begin{array}{c}\text { relative error } \\
{[\%]}\end{array}$ \\
\hline \hline 0.10 & 1.8 & 1.8 & 17.9 & 0.2 \\
\hline 0.30 & 5.4 & 5.4 & 53.7 & 0.5 \\
\hline 0.60 & 10.7 & 10.7 & 107.4 & 1.1 \\
\hline 1.50 & 26.9 & 26.9 & 268.5 & 2.7 \\
\hline 3.00 & 53.7 & 53.7 & 537.1 & 5.4 \\
\hline
\end{tabular}

Analyzing the Table 3, it can be stated that the most accurate determination of boundary points' location is particularly important in case of parcels with small surface area. Then, a significant increase of relative errors is noticeable. However, the achieved average errors of surface areas for large objects confirm that accurate determining the location of boundary bend points is equally important here.

Taking into account the results of examinations and the current state of cadastral data, the validity of revealing the parcel surface areas with the precision up to $1 \mathrm{~m}^{2}$, should be also considered. This solution can suggest that the surface areas revealed in EGiB are characterized by a similar level of accuracy. Unfortunately, this postulate is usually not fulfilled, in particular in case of large parcels with elongated shape, located in non-urbanized areas. Therefore, revealing the surface areas in ares is a reasonable solution, until the quality of data is not improved. In turn, on urbanized areas, where data on the boundaries are acquired mainly with the direct method, the recording precision of up to $1 \mathrm{~m}^{2}$ can be considered as appropriate, and even as necessary, taking into account the tasks of EGiB.

It should be recalled here that in accordance with $\S 2$ of the Regulation of the Minister of Administration and Digitalization of 29 November, 2013, amending the regulation on the register of land and buildings [6], the data revealed in EGiB maintain their validity until obtaining the materials on the basis of which it will be possible to calculate the surface area of individual parcels, in accordance with binding standards. It means that in case when the value of BPP attribute assigned to the parcel boundary points equals to 3, 4, 5 and 6 (so they do not meet the accuracy requirements stipulated in $\S 61$ of the Regulation 2001), then the surface areas calculated on their basis cannot be applied for completing the statutory tasks of EGiB. They should be considered as having only the information character. In such cases the surface areas, which were revealed in existing, original documentation, are used, in order to, inter alia, determine the basis for calculating the real estate tax or designating the real estate in the land and mortgage register. It is confirmed also by $\S 83$ of the amended Regulation 2001. However, it should not be expected that these data 
will be characterized of sufficiently high accuracy and reliability. In many cases the surface areas determined on the basis of coordinates of boundary points which do not fulfil the binding technical standards can appear better than the surface areas revealed in original registers. This problem is important also in the aspect of data synchronization in the descriptive and spatial part of real estate cadastre. Therefore, the boundary points with the BPP value over 2 have not been omitted in further considerations.

In order to depict the influence of geometry on the value of surface area average error, the chart for the case of two parcels with the shape described by four boundary bend points and with the determined values of BPP attribute, has been prepared (Fig. 3).

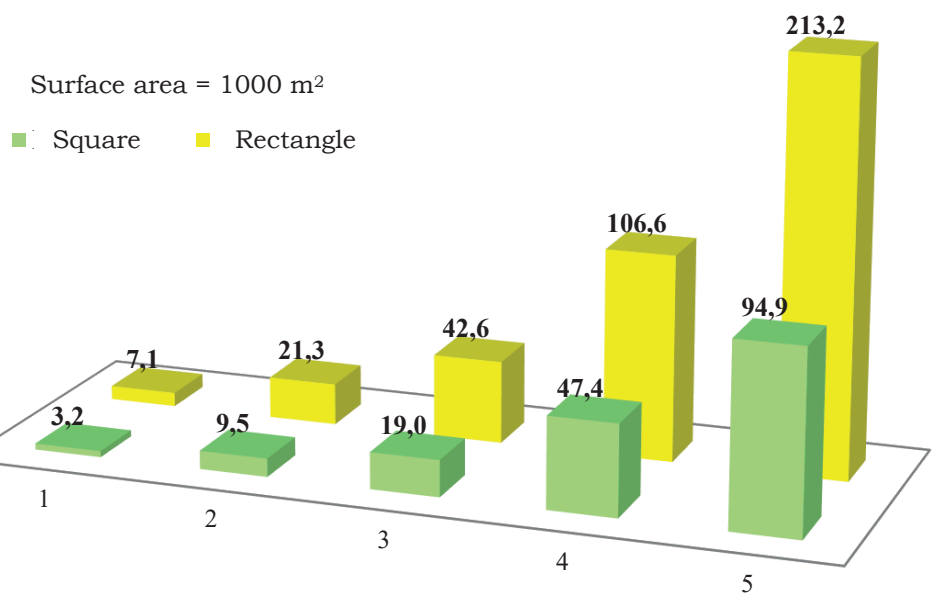

Fig. 3. Surface area average errors $\left[\mathrm{m}^{2}\right]$, depending on parcel shape and the value of boundary points BPP attribute

It is easy to notice that in case of figures with elongated shape the influence of boundary points' location errors on the accuracy of surface area determination is strongly higher (in considered case over twice). Therefore, the bigger distance between the points, the higher influence of their location errors on the accuracy of surface area analytical determination. It results directly from the formulas (6) and (8). Obviously, with higher number of evenly distributed points of boundary bends, the average errors of surface areas will achieve lower values.

The mentioned issue of differences in the distribution of boundary points is illustrated well on the schemes below (Fig. 4).
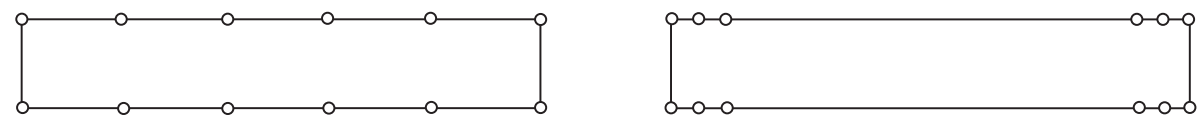

Fig. 4. Various cases of the arrangement of parcels' boundary points 
Undoubtedly, the first case is significantly more beneficial. The uniform distribution of the parcel's boundary bend points causes that the square of the shortest diagonal located opposite to the $i^{\text {th }}$ point assumes lower values, which has a very positive influence on the accuracy of analytical determining the parcel surface area. Such conclusion is confirmed by calculations (presented in the Table 4) which have been performed for an object having the shape of rectangle, with the surface area of $10000 \mathrm{~m}^{2}$.

Table 4. Surface area average errors $\left[\mathrm{m}^{2}\right]$ depending on distribution and number of boundary points with determined values of BPP attribute

\begin{tabular}{||c|c|c|c|c|c|c|c|c|c|c||}
\cline { 2 - 11 } \multicolumn{1}{c|}{} & \multicolumn{5}{c|}{ Points distributed evenly } & \multicolumn{3}{c||}{ Points distributed close to each other } \\
\hline \hline 1 & 4 & 8 & 12 & 16 & 20 & 4 & 8 & 12 & 16 & 20 \\
\hline \hline 2 & 106.2 & 79.1 & 63.8 & 54.8 & 48.8 & 106.2 & 105.1 & 103.0 & 100.9 & 98.8 \\
\hline 3 & 212.3 & 158.3 & 127.6 & 109.6 & 97.6 & 212.3 & 210.2 & 206.0 & 201.8 & 197.6 \\
\hline 4 & 530.8 & 395.7 & 318.9 & 274.0 & 243.9 & 530.8 & 525.5 & 515.0 & 504.5 & 494.0 \\
\hline 5 & 1061.5 & 791.4 & 637.8 & 548.0 & 487.8 & 1061.5 & 1051.0 & 1030.0 & 1009.0 & 988.1 \\
\hline
\end{tabular}

Therefore, it should be emphasized once again that the higher number of boundary points, the higher accuracy of surface area determination. However, to make this statement fully true, it should be added that the even distribution of boundary points is also the necessary condition. In other case it should not be expected that the improvement in the accuracy of analytical calculations of surface areas will be significant.

The results of conducted examinations allowed formulating the conclusions regarding the factors which affect the final value of surface area average error. However, it should be noted that their influence is always cumulative and correlated. It is worth emphasizing that aiming at increasing the accuracy of analytical determination of surface areas we are able to influence only the errors of boundary points' location. Intervention in geometry and the number of boundary bend points is neither possible nor even rational for that purpose. It means that the systematic adjustment of spatial data to technical requirements stipulated in regulations is the only way to increase the reliability and improve the functioning of EGiB.

Finally, Table 5 presenting the values of surface area average errors for selected parcels within the Michałowice cadastral unit has been prepared. The obtained results confirm that uncritical use of the surface areas revealed in EGiB is not justified currently. 
Table 5. Results of surface area calculations for selected parcels, including the accuracy assessment (cadastral unit: Michałowice)

\begin{tabular}{|c|c|c|c|c|c|c|c|}
\hline No. & Parcel no. & $\begin{array}{c}\text { Average } \\
\text { BPP } \\
{[\mathrm{m}]}\end{array}$ & $\begin{array}{c}\text { Surface area } \\
\qquad\left[\mathrm{m}^{2}\right]\end{array}$ & $\begin{array}{c}\text { Average } \\
\text { error } \\
{\left[\mathrm{m}^{2}\right]}\end{array}$ & $\begin{array}{c}\text { Relative } \\
\text { error } \\
{[\%]}\end{array}$ & \multicolumn{2}{|c|}{$\begin{array}{l}\text { Interval including } \\
\text { parcel surface area } \\
\qquad(P=95 \%)\end{array}$} \\
\hline \multicolumn{8}{|c|}{ Undeveloped parcels } \\
\hline 1 & 16 & 2.26 & 14239 & 277.5 & 1.9 & 13684 & 14794 \\
\hline 2 & $128 / 3$ & 3.00 & 7636 & 255.7 & 3.3 & 7124 & 8147 \\
\hline 3 & 228 & 3.00 & 7682 & 350.6 & 4.6 & 6981 & 8383 \\
\hline 4 & 643 & 1.91 & 17063 & 313.3 & 1.8 & 16437 & 17690 \\
\hline 5 & 589 & 2.38 & 21137 & 299.1 & 1.4 & 20539 & 21735 \\
\hline 6 & 601 & 1.84 & 10891 & 275.1 & 2.5 & 10341 & 11441 \\
\hline 7 & $608 / 1$ & 0.97 & 26655 & 325.9 & 1.2 & 26004 & 27307 \\
\hline 8 & $406 / 2$ & 1.47 & 19840 & 219.3 & 1.1 & 19401 & 20278 \\
\hline 9 & $482 / 5$ & 1.19 & 20014 & 769.0 & 3.8 & 18476 & 21552 \\
\hline 10 & $130 / 3$ & 1.14 & 12141 & 190.9 & 1.6 & 11759 & 12523 \\
\hline \multicolumn{8}{|c|}{ Built-up parcels } \\
\hline 11 & $2 / 2$ & 1.15 & 6358 & 183.0 & 2.9 & 5992 & 6724 \\
\hline 12 & $10 / 6$ & 1.26 & 1347 & 61.2 & 4.5 & 1224 & 1469 \\
\hline 13 & $82 / 4$ & 1.26 & 4307 & 154.3 & 3.6 & 3998 & 4615 \\
\hline 14 & 1011 & 1.95 & 1796 & 74.3 & 4.1 & 1647 & 1944 \\
\hline 15 & 223 & 2.52 & 1030 & 100.6 & 9.8 & 828 & 1231 \\
\hline 16 & $229 / 1$ & 2.10 & 7700 & 200.7 & 2.6 & 7299 & 8101 \\
\hline 17 & 463 & 2.52 & 1640 & 113.1 & 6.9 & 1413 & 1866 \\
\hline 18 & 733 & 1.76 & 2806 & 109.1 & 3.9 & 2588 & 3025 \\
\hline 19 & 708 & 2.24 & 1261 & 137.9 & 10.9 & 985 & 1537 \\
\hline 20 & $879 / 1$ & 3.00 & 3628 & 152.0 & 4.2 & 3324 & 3932 \\
\hline
\end{tabular}

\section{Summary}

The conducted analyses allowed for the determining the influence of boundary point location errors, their number and parcel geometry on the accuracy of surface area analytical determination. It appears that the total influence of considered factors can cause very negative effects in this aspect. It should be stated that in the 
current state of cadastral data regarding the parcels' boundaries it would be reasonable to introduce the surface area attribute, which would indicate the accuracy of its determination (e.g. relative error). Such information should be also revealed on extracts of land registry. It should be remembered that the principle of public credibility of land and mortgage registers is not expanded on the designation of real estate. Therefore, it can be stated that introducing the proposed solution would be the next step towards ensuring the protection of property interests for the parties of real estate transactions.

The final conclusion from the conducted considerations has been formulated in the following manner: cadastral data regarding parcel boundary require still to be corrected in the scope of their accuracy and reliability. However, this postulate is systematically carried out. When all boundary points revealed in EGiB are characterized of reliably determined values of ZRD attribute, equalling to 1, 5 and 6, and also 3 in case of agricultural land, and simultaneously the requirements for accuracy stipulated in $\S 61$, section 1 of the Regulation 2001 are fulfilled, then the problem of average errors of parcels' surface areas will lose any significance, irrespectively of occurred circumstances. Cadastral data regarding the parcels could be considered, in advance, as sufficiently accurate and reliable for carrying out any statutory tasks.

\section{References}

[1] Bieda A., Hanus P., Jasińska E., Preweda E.: Accuracy of determination of real estate area. [in:] The 9th International Conference "Environmental Engineering" 22-23 May 2014, Vilnius, Lithuania. Selected Papers, Vilnius Gediminas Technical University Press “Technika”, 2014.

[2] Hanus P.: Ocena przydatności dokumentacji byłego katastru austriackiego dla potrzeb prac geodezyjnych. Kraków 2006 [PhD thesis, unpublished].

[3] Hanus P., Hycner R., Kwartnik A.: Analiza terminologiczna wybranych problemów katastru i zagadnień pokrewnych. Część 1. Działka, granica, nieruchomość. Geodeta Magazyn Geoinformacyjny, nr 10, 2013, pp. 15-22.

[4] Hycner R.: Podstawy katastru. Wydawnictwa Naukowo-Dydaktyczne AGH, Kraków 2004.

[5] Instrukcja techniczna G-5 Ewidencja gruntów i budynków [annex to Zarządzenie nr 16 Głównego Geodety Kraju z dnia 3 listopada 2003 r.].

[6] Rozporzadzenie Ministra Administracji i Cyfryzacji z dnia 29 listopada 2013 r. zmieniajace rozporządzenie w sprawie ewidencji gruntów i budynków. Dz.U. 2013, poz. 1551.

[7] Rozporzadzenie Ministra Rozwoju Regionalnego i Budownictwa z dnia 29 marca 2001 r. w sprawie ewidencji gruntów i budynków. Dz.U. 2015, poz. 542 - tekst jednolity z późniejszymi zmianami [Journal of Laws 2015, item 542 - consolidated text with the amendments]. 
[8] Rozporzadzenie Ministra Spraw Wewnętrznych i Administracji z dnia 9 listopada 2011 r. w sprawie standardów technicznych wykonywania geodezyjnych pomiarów sytuacyjnych $i$ wysokościowych oraz opracowywania i przekazywania wyników tych pomiarów do państwowego zasobu geodezyjnego i kartograficznego. Dz.U. 2011, nr 263, poz. 1572 [Journal of Laws 2011, no. 263, item 1572].

[9] Ustawa z dnia 17 maja 1989 r. Prawo geodezyjne i kartograficzne. Dz.U. 2015, poz. 520 - tekst jednolity z późniejszymi zmianami [Journal of Laws 2015, item 520 - consolidated text with the amendments]. 